Letter to Editor

\title{
Note on the formula of brunogeierite and the first bond-valence parameters for $\mathrm{Ge}^{2+}$
}

\author{
Jan CEMPÍREK ${ }^{1,2, *}$, Lee A. GROAT ${ }^{1}$ \\ ${ }^{1}$ Department of Earth, Ocean and Atmospheric Sciences, University of British Columbia, 2020-2207 Main Mall, Vancouver, BC, \\ V6T1Z4Canada; jcempirek@mzm.cz \\ ${ }^{2}$ Department of Mineralogy and Petrography, Moravian Museum, Zelný trh 6, 65937 Brno, Czech Republic \\ * Corresponding author
}

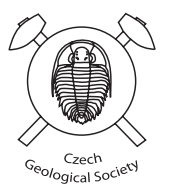

\begin{abstract}
Brunogeierite is a rare Ge-mineral with a spinel-type structure. Inconsistences in the brunogeierite formula suggesting divalent germanium in its structure have occurred since its description. A review of the published data and bond-valence calculations show that the correct ideal end-member formula of brunogeierite is $\left(\mathrm{Fe}^{2+}\right)_{2} \mathrm{Ge}^{4+} \mathrm{O}_{4}$. The mineral is newly classified as a nesogermanate member of the ringwoodite group (Strunz classification 9.AC.15). Formal correction of the brunogeierite formula and classification was approved by the IMA Commission on New Minerals, Nomenclature and Classification (IMA-CNMNC) as proposal IMA 11-A. In order to perform bond-valence calculations using divalent germanium, new bond-valence parameters for $\mathrm{Ge}^{2+}-\mathrm{O}\left(\mathrm{R}_{0}=1.778 \AA, \mathrm{B}=0.37 \AA\right)$ and $\mathrm{Ge}^{2+}-\mathrm{Cl}\left(\mathrm{R}_{0}=2.156 \AA, \mathrm{B}=0.37\right.$ $\AA$ ) were evaluated.
\end{abstract}

Keywords: germanium, spinel-type structure, ringwoodite group, bond-valence model Received: 25 October 2012; accepted: 5 March 2013; handling editor: R. Skála

\section{Introduction}

Brunogeierite is a rare Ge-mineral with a spinel-type structure. Since its discovery in Tsumeb, Namibia (Otteman and Nuber 1972) it has been described from at least 12 other localities in the French Pyrenees (Aye et al. 1978; Johan et al. 1983; Johan and Oudin 1986). The brunogeierite structure and experimental stability constraints are well known (Otteman and Nuber 1972; Hariya and Wai 1970; Julliot et al. 1987; Welch et al. 2001); however, its formula is ambiguous. In the updated 2011 version of "IMA List of Minerals" and in earlier books and reviews (e.g., Fleischer and Mandarino 1995; Anthony et al. 1997), brunogeierite was listed with the formula $\mathrm{Ge}^{2+}\left(\mathrm{Fe}^{3+}\right)_{2} \mathrm{O}_{4}$ and the respective Strunz classification was 4.BB.05 (Oxides, Spinel Group). The presence of $\mathrm{Ge}^{2+}$ in brunogeierite has also been non-critically adopted elsewhere (e.g., Höll et al. 2007). However, the low oxidation state of germanium $\left(\mathrm{Ge}^{2+}\right)$ along with the high oxidation state of iron $\left(\mathrm{Fe}^{3+}\right)$ in the same compound is suspicious and, since synthetic compounds with $\mathrm{Ge}^{2+}$ are very rare and usually unstable in humid air (e.g., Messer 1978; Thiele et al. 1987), the presence of $\mathrm{Ge}^{2+}$ in a natural phase is unlikely.

This study clarifies the inconsistences in the brunogeierite formula and provides new bond-valence parameters for bonds of $\mathrm{Ge}^{2+}$ with oxygen and chlorine. A review of published data and bond-valence calculations shows that the correct ideal end-member formula of brunogeierite is $\left(\mathrm{Fe}^{2+}\right)_{2} \mathrm{Ge}^{4+} \mathrm{O}_{4}$. Since the Strunz classification scheme ca- tegorizes silicates and germanates in the same group, the mineral is newly classified as a nesogermanate, a member of the ringwoodite group (Strunz classification 9.AC.15). Formal correction of the brunogeierite formula and classification was approved by the IMA Commission on New Minerals, Nomenclature and Classification (IMACNMNC) as proposal IMA 11-A (Williams et al. 2011).

\section{Brunogeierite formula}

Papers published on brunogeierite have not provided valence states for the cations; the original formula reported by Otteman and Nuber (1972) is $\left(\mathrm{GeFe}_{2} \mathrm{O}_{4}\right)_{x} \cdot\left(\mathrm{Fe}_{3} \mathrm{O}_{4}\right)_{1-x}$ with $x$ equal to 0.87 and 0.95 in the two analyzed samples. However, the analytical data were always presented as $\mathrm{GeO}_{2}$ and $\mathrm{FeO}$ (Otteman and Nuber 1972; Johan et al. 1983), although sometimes minor amount of $\mathrm{Fe}^{3+}$ $(\leq 0.172$ apfu $)$ was calculated in order to match the ideal stoichiometry $\left(\mathrm{Fe}^{2+}, \mathrm{R}^{3+}\right)_{2}\left(\mathrm{Ge}, \mathrm{Fe}^{3+}\right) \mathrm{O}_{4}$ (Johan et al. 1983). Significant inconsistency has occurred especially in subsequent mineral listings and derivative reports, where brunogeierite has been listed either as $\left(\mathrm{Ge}_{x}, \mathrm{Fe}_{1-x}\right) \mathrm{Fe}_{2} \mathrm{O}_{4}$ (Fleischer 1973), $\left(\mathrm{Ge}^{2+}, \mathrm{Fe}^{2+}\right)\left(\mathrm{Fe}^{3+}\right)_{2} \mathrm{O}_{4}$ (e.g., Fleischer 1980; Fleischer and Mandarino 1995; Anthony et al. 1997), $\mathrm{Fe}_{2}{ }_{2}^{3+}\left(\mathrm{Ge}^{2+}, \mathrm{Fe}^{2+}\right) \mathrm{O}_{4}$ (Bernard and Hyršl 2004), $\mathrm{GeFe}_{2} \mathrm{O}_{4}$ (Mandarino and Back 2004) or $\left(\mathrm{Ge}^{2+}, \mathrm{Fe}\right) \mathrm{Fe}_{2} \mathrm{O}_{4}$ (Spiridonov and Murashko 2010).

Brunogeierite was referred to as a nesogermanate (Otteman and Nuber 1972) or germanate and an ana- 
logue of $\gamma-\mathrm{Fe}_{2} \mathrm{SiO}_{4}$ (Welch et al. 2001). Hariya and Wai (1970) studied miscibility of $\mathrm{Fe}_{2} \mathrm{SiO}_{4}$ and $\mathrm{Fe}_{2} \mathrm{GeO}_{4}$ with spinel-type structures. In all three publications where brunogeierite chemistry or structure were directly studied (Otteman and Nuber 1972; Johan et al. 1983; Welch et al. 2001), there is no note on the alleged divalent state of germanium or prevailing trivalent state of iron.

Churbakov et al. (1964) reported synthesis of magnetite containing $\mathrm{Ge}^{2+}$ under nitrogen atmosphere using rather unclear synthesis procedure from $\mathrm{Fe}$-sulphate and $\mathrm{GeCl}_{2}$ in alkaline solution. However, the reported powder $\mathrm{X}$-ray diffraction patterns of the precipitates heated at $400{ }^{\circ} \mathrm{C}$ in a stream of $\mathrm{CO}_{2}$ strongly resemble those for mixtures of magnetite, $\mathrm{GeO}_{2}$ and hematite; therefore, the synthesis products do not seem to be sufficiently characterized.

\section{Crystal chemistry of ionic $\mathrm{Ge}^{2+}$-compounds}

Compounds containing $\mathrm{Ge}^{2+}$ have been synthesized in the past but are never observed in nature. Germanium with formal valence $2+$ is stable especially in covalent bonds with $\mathrm{S}, \mathrm{Se}, \mathrm{Te}, \mathrm{As}, \mathrm{P}$ and $\mathrm{N}$; ionic bonds with halogenides and oxygen are less frequent. Ratios of ionic/covalent bond components are disputable (e.g. Höll et al. 2007); covalent bonding becomes more important for bromides and iodides but it is significant for bonds with anions of high electronegativity $(\mathrm{O}, \mathrm{F}, \mathrm{Cl})$. Ionic bonding in $\mathrm{Ge}^{2+}$ compounds is more significant than in $\mathrm{Ge}^{4+}$ compounds due to lower electronegativity (cf. Li and Xue 2006).

Only three of 31 ionic structures with $\mathrm{Ge}^{2+}$ in the ICSD database (Fachinformationszentrum Karlsruhe 2011) contain $\mathrm{Ge}^{2+}-\mathrm{O}$ bonds. Synthesis of ionic compounds of $\mathrm{Ge}^{2+}$ always requires strong reducing agents (the most commonly used is hypophosphorous acid $\mathrm{H}_{3} \mathrm{PO}_{2}$; Everest 1953 ) and an inert atmosphere (Everest 1953; Lee and Weng 2008). In ionic compounds with halogens or $\mathrm{O}^{2-}$, divalent germanium typically occurs in triangular pyramidal coordination, with a stereochemically active lone electron pair oriented opposite to the triangle of anions. Bond lengths between $\mathrm{Ge}^{2+}$ and $\mathrm{O}^{2-}$ range from 1.86 to $1.95 \AA$ (Weakley and Watt 1979; Lee and Weng 2008).

For the purpose of demonstration of bond-valence sums (Brown 2002) of Ge in brunogeierite, we examined the three compounds with $\mathrm{Ge}-\mathrm{O}$ bonds (Tab. 1). Because no bond-valence parameters for $\mathrm{Ge}^{2+}-\mathrm{O}$ have been published to date, we used the structures of $\mathrm{GeCl}\left(\mathrm{H}_{2} \mathrm{PO}_{2}\right)$ and $\mathrm{Na}\left[\mathrm{Ge}_{4}\left(\mathrm{PO}_{4}\right)_{3}\right]$ for their calculation; the quality of the $\mathrm{Ge}_{2}\left(\mathrm{H}_{2} \mathrm{PO}_{2}\right)_{6}$ structure model was insufficient for the calculation because of the unresolved positional disorder of the $\mathrm{Ge}^{2+}$ site reported by Weakley (1983). In the case of the $\mathrm{GeCl}\left(\mathrm{H}_{2} \mathrm{PO}_{2}\right)$ structure, $\mathrm{Ge}^{2+}$ is bonded to one chlorine and two oxygen atoms; since the calculation required bondvalence (BV) parameters for $\mathrm{Ge}^{2+}-\mathrm{Cl}$ as well, we calculated them using four other compounds where $\mathrm{Ge}^{2+}$ is bonded to chlorine atoms only (Tab. 1). Bond valence parameters $R_{0}$ were obtained according to Brown (2002) as an average of $\mathrm{R}_{0 \mathrm{i}}$ values for all $\mathrm{Ge}^{2+}$-polyhedra. $\mathrm{R}_{0 \mathrm{i}}$ is defined as:

$$
R_{0 i}=B \times \ln \left(V_{i} / \sum \exp ^{-\frac{R_{i j}}{B}}\right)
$$

where $\mathrm{B}$ is a bond-valence parameter $(\mathrm{B}=0.37 \AA), \mathrm{V}_{i}$ the formal valence of the cation $(\mathrm{V}=2)$, and $\mathrm{R}_{i j}$ the bond length between atoms $i$ and $j$. Advanced least-squares fitting of $\mathrm{R}_{0}$ and $\mathrm{B}$ constants (e.g. Krivovichev 2012, and references therein) was not possible due to the lack of structural data.

The calculated bond-valence parameters may be influenced by interactions of the free electron pair with adjacent atoms. In $\mathrm{GeCl}\left(\mathrm{H}_{2} \mathrm{PO}_{2}\right)$, the distance between $\mathrm{Ge}$ and $\mathrm{P}$ is $4.17 \AA$, and in $\mathrm{Na}\left[\mathrm{Ge}_{4}\left(\mathrm{PO}_{4}\right)_{3}\right]$ the two neighboring Ge atoms are $3.94 \AA$ apart; these distances are too long for significant covalent interactions. This is in agreement with Wang and Liebau (1996) who showed correlation between the $<\varphi-\mathrm{Sb}^{3+}-\varphi>$ bond angles and free electron pair interaction for $\mathrm{Sb}^{3+}$ in triangular pyramidal coordination. All compounds used for the calculation of $\mathrm{BV}$ parameters feature $\mathrm{O}-\mathrm{Ge}-\mathrm{O}$ angles between 90 and $100^{\circ}$ (Tab. 1), suggesting only very weak interactions.

Tab. 1 Calculation of bond-valence parameters for $\mathrm{Ge}^{2+}-\mathrm{Cl}$ and $\mathrm{Ge}^{2+}-\mathrm{O}$

\begin{tabular}{|c|c|c|c|}
\hline Compound (reference) & $<\mathrm{Ge}-\varphi>[\AA]$ & $\mathrm{R}_{0 \mathrm{i}}[\AA]$ & $<\varphi-\mathrm{Ge}-\varphi>$ \\
\hline $\mathrm{N}\left(\mathrm{CH}_{3}\right)_{4} \mathrm{GeCl}_{3}($ Depmeier et al. 1980) & 2.294 & 2.143 & $95.2^{\circ}$ \\
\hline $\mathrm{RbGeCl}_{3}\left(\right.$ Messer 1978) $_{4}$ & 2.311 & 2.161 & $94.5^{\circ}$ \\
\hline 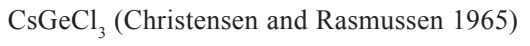 & 2.272 & 2.122 & $93.5^{\circ}$ \\
\hline \multirow[t]{2}{*}{$\mathrm{CsGeCl}_{3}$ (Thiele et al. 1987) } & 2.348 & 2.198 & $94.2^{\circ}$ \\
\hline & \multicolumn{2}{|c|}{$\mathrm{R}_{0}\left(\mathrm{Ge}^{2+}-\mathrm{Cl}\right)=2.156$} & \\
\hline $\begin{array}{l}\mathrm{Na}\left[\mathrm{Ge}_{4}\left(\mathrm{PO}_{4}\right)_{3}\right] \\
\text { (Lee and Weng 2008) } \\
\mathrm{GeCl}\left(\mathrm{H}_{2} \mathrm{PO}_{2}\right) \\
\text { (Weakley and Watt 1979) }\end{array}$ & $\begin{aligned}<\mathrm{Ge} 1-\mathrm{O}> & : 1.908 \\
<\mathrm{Ge} 2-\mathrm{O}> & : 1.905 \\
<\mathrm{Ge}-\mathrm{Cl}>: & 2.351 \\
<\mathrm{Ge}-\mathrm{O}> & : 1.953 \\
& \mathrm{R}_{0}\left(\mathrm{Ge}^{2+}-\right.\end{aligned}$ & $\begin{array}{r}1.758 \\
1.753 \\
- \\
1.824 \\
=1.778\end{array}$ & $\begin{array}{l}88.9^{\circ} \\
88.0^{\circ} \\
90.2^{\circ}\end{array}$ \\
\hline
\end{tabular}

Note: all structures at ambient temperature $\left(20-25^{\circ} \mathrm{C}\right) . \mathrm{B}=0.37 \AA$ for both $\mathrm{R}_{0}\left(\mathrm{Ge}^{2+}-\mathrm{Cl}\right)$ and $\mathrm{R}_{0}\left(\mathrm{Ge}^{2+}-\mathrm{O}\right)$ 
Tab. 2 Brunogeierite bond-valence formula models

(1)

Formula

Site occ.

Avg. cat. charge

$\sum \mathrm{BV}$

$\underline{\Delta}$

$\mathrm{Ge}^{2+}\left(\mathrm{Fe}^{3+}\right)_{2} \mathrm{O}_{4}$
(2)

$\left(\mathrm{Fe}^{2+}\right)_{2}\left(\mathrm{Ge}^{4+}\right) \mathrm{O}_{4}$

(3)

BV-optimized formula

\begin{tabular}{llllccc}
$\mathrm{O}^{2-}$ & $\mathrm{Fe}^{2+}$ & $\mathrm{Ge}^{4+}$ & $\mathrm{O}^{2-}$ & $\mathrm{Fe}^{2+}{ }_{0.904} \mathrm{Fe}^{3+}{ }_{0.096}$ & $\mathrm{Ge}^{4+}{ }_{0.808} \mathrm{Fe}^{3+}{ }_{0.192}$ & $\mathrm{O}^{2-}$ \\
-2 & 2 & 4 & -2 & 2.096 & 3.808 & -2 \\
-2.11 & 2.05 & 3.75 & -1.96 & 2.059 & 3.772 & -1.972 \\
-0.11 & -0.05 & $\mathbf{0 . 2 5}$ & -0.04 & 0.037 & 0.036 & -0.028 \\
\hline
\end{tabular}

(1) model with $\mathrm{Ge}^{2+}$ and formula $\mathrm{Ge}^{2+}\left(\mathrm{Fe}^{3+}\right)_{2} \mathrm{O}_{4}$;

(2) model with $\mathrm{Ge}^{4+}$ and formula $\left(\mathrm{Fe}^{2+}\right)_{2}\left(\mathrm{Ge}^{4+}\right) \mathrm{O}_{4}$;

(3) model with $\mathrm{Ge}^{4+}$ and disordered bond-valence optimized formula;

$\Delta=$ difference between the average cation charge and the bond-valence sum.

\section{Bond-valence calculations in brunogeierite}

The bond-valence model (Brown and Altermatt 1985; Brown 2002) is frequently used in verification and modeling of inorganic crystal structures using empirical relationships between bond length and bond valence. The bond valence is related to the bond length using the equation:

$$
S_{i j}=\exp ^{\frac{R_{0}-R_{i j}}{B}}
$$

where $\mathrm{R}_{i j}$ represents the bond length from atom $i$ to atom $j, \mathrm{~S}_{i j}$ the corresponding bond valence, and $\mathrm{R}_{0}$ and $\mathrm{B}$ are empirical parameters. The sum of all experimental bond valences $\mathrm{S}_{\mathrm{ij}}$ around the atom $i$ is equal to its formal valence $V_{i}$ (Brown and Altermatt 1985; Brown 2002).

The bond-valence model was employed to calculate the valence states of $\mathrm{Fe}$ and $\mathrm{Ge}$ in three individual cases: 1) all $\mathrm{Ge}$ as $\mathrm{Ge}^{2+}$ and all $\mathrm{Fe}$ as $\mathrm{Fe}^{3+}$,2) all $\mathrm{Ge}$ as $\mathrm{Ge}^{4+}$ and all $\mathrm{Fe}$ as $\mathrm{Fe}^{2+}$, and 3) bond-valence optimized formula with minor $\mathrm{Fe}^{3+}$ disordered between tetrahedral and octahedral sites. The brunogeierite structure and bond lengths reported by Welch et al. (2001) were used. Bond-valence calculations results for brunogeierite are listed in Tab. 2 .

The unsuitable character of the $\mathrm{Ge}^{2+}$-bearing model is proven by the disagreement between the formal average cation charges and calculated bond-valence sums of tetrahedral and octahedral sites in brunogeierite (Tab. 2, model 1). On the other hand, the slightly lower bondvalence sums in the model with structural sites fully occupied by one cation species (model 2) suggest minor substitutions of $\mathrm{Fe}^{3+}$ at both sites. The bond-valence optimized formula of brunogeierite, with $\mathrm{Fe}^{3+}$ employed (model 3), is $\left(\mathrm{Fe}^{2+}{ }_{0.904} \mathrm{Fe}^{3+}{ }_{0.096}\right)_{2}\left(\mathrm{Ge}^{4+}{ }_{0.808} \mathrm{Fe}^{3+}{ }_{0.192}\right) \mathrm{O}_{4}$.

\section{Discussion and summary}

The literature review shows that previous studies have never reported the presence of $\mathrm{Ge}^{2+}$ or prevalence of $\mathrm{Fe}^{3+}$ in the brunogeierite formula. The error regarding the valence state of $\mathrm{Fe}$ and Ge probably started in Fleischer
(1980) and could be due to the title of the original paper (Otteman and Nuber 1972) where the term "GermaniumFerritspinell" is used ("Ferrit" is a common chemical term for Fe-spinel). This might have caused the subsequent confusion of terms ("Ferrit" vs. "ferric"?) and valence states.

Brunogeierite has a spinel-type structure, with fully ordered $\mathrm{Ge}$ and $\mathrm{Fe}$ atoms at tetrahedral and octahedral sites, respectively (normal spinel structure; Welch et al. 2001). The bond length $<\mathrm{Ge}-\mathrm{O}>=1.771$ (2) $\AA$ for $\mathrm{Ge}$ at the tetrahedral site in brunogeierite is slightly shorter than those reported for the synthetic germanate spinels $\mathrm{Mg}_{2} \mathrm{GeO}_{4}, \mathrm{Co}_{2} \mathrm{GeO}_{4}$ and $\mathrm{Ni}_{2} \mathrm{GeO}_{4}(1.775-1.801 \AA)$. The shorter bond length in brunogeierite can be explained as an effect of minor $\mathrm{Fe}^{3+}$ present at the $\mathrm{Ge}^{4+}$ site, as indicated by the results of the bond valence calculations.

The ideal end-member formula is therefore $\left(\mathrm{Fe}^{2+}\right)_{2} \mathrm{Ge}^{4+} \mathrm{O}_{4}$. Small amounts of $\mathrm{Fe}^{3+}$ occurring at the tetrahedral and octahedral sites suggest minor solid solution with a magnetite component. Since the Strunz classification scheme categorizes silicates and germanates in the same group, the mineral should be classified as a nesogermanate member of the ringwoodite group (Strunz classification 9.AC.15).

Acknowledgements. Work on the manuscript was financially supported by the Ministry of Culture of the Czech Republic as part of its long-term conceptual development programme for research institutions (the Moravian $\mathrm{Mu}$ seum, MK000094862), and by the Natural Sciences and Engineering Research Council of Canada in the form of a Discovery Grant to LAG.

\section{References}

Anthony JW, Bideaux RA, Bladh KW, Nichols MC (1997) Handbook of Mineralogy. Volume III - Halides, Hydroxides, Oxides. Materials Data Publishing. Accessed on March 4, 2013, at http://www.handbookofmineralogy. org/

Aye F, Bouladon J, Рicot P, Pouit G (1978) Quelques exemples d'apports de la minéralogie à la connaissance 
et la recherche des gîtes minéraux. Bull Minéral 101: 139-147

Bernard JH, HyršL J (2004) Minerals and Their Localities. Granit, Prague, pp 1-807

Brown ID (2002) The Chemical Bond in Inorganic Chemistry: The Bond Valence Model. IUCr Monographs on Crystallography 12. Oxford University Press, pp 1-278

Brown ID, Altermatt D (1985) Bond-valence parameters obtained from a systematic analysis of the Inorganic Crystal Structure Database. Acta Cryst B41: 244-247

Christensen AN, Rasmussen SE (1965) A ferroelectric chloride of perowskite type. Crystal structures of $\mathrm{CsGeCl}_{3}$. Acta Chem Scand 19: 421-428

Churbakov VF, Gordon SA, Menkovskit MA (1964) Synthesis of magnetite containing bivalent germanium. Geochem Int 3: 465-467

Depmeier W, Möller A, Klaska K-H (1980) The structure of antiferroelectric tetrametylammonium trichlorogermanate(II) at room temperature. Acta Cryst B36: 803-807

EVEREST DA (1953) The chemistry of bivalent germanium compounds. Part IV. Formation of germanous salts by reduction by hypophosphorous acid. J Chem Soc 1953: $4117-4120$

Fachinformationszentrum KarlsRUhe (2003) Inorganic Crystal Structure Database, version 2011-2.

Fleischer M (1973) New mineral names. Amer Miner 58: 347-349

Fleischer M (1980) Glossary of Mineral Species 1980. The Mineralogical Record Inc., Tucson, pp 1-191

Fleischer M, Mandarino JA (1995) Glossary of Mineral Species 1995. The Mineralogical Record Inc., Tucson, pp 1-280

HARIYA Y, WAI CM (1970) The stability and phase transition of the system $\mathrm{Fe}_{2} \mathrm{GeO}_{4}-\mathrm{Fe}_{2} \mathrm{SiO}_{4}$. J Fac Sci Hokkaido Univ, Series 4, 14: 355-363

Höll R, Kling M, Schroll E (2007) Metallogenesis of germanium - a review. Ore Geol Rev 30: 145-180

Johan Z, Oudin E (1986) Présence de grenats, $\mathrm{Ca}_{3} \mathrm{Ga}_{2}\left(\mathrm{GeO}_{4}\right)_{3}, \mathrm{Ca}_{3} \mathrm{Al}_{2}\left[(\mathrm{Ge}, \mathrm{Si}) \mathrm{O}_{4}\right]_{3}$ et d'un équivalent ferrifère, germanifère et gallifère de la sapphirine, $\mathrm{Fe}_{4}(\mathrm{Ga}, \mathrm{Sn}, \mathrm{Fe})_{4}(\mathrm{Ga}, \mathrm{Ge})_{6} \mathrm{O}_{20}$, dans la blende des gisements de la zone axiale pyrénéenne. Conditions de formation des phases germanifères et gallifères. C R Acad Sci Paris Série II 303: 811-816

Johan Z, Oudin E, PICOT P (1983) Analogues germanifères et gallifères des silicates et oxydes dans les gisements de zinc des Pyrénées centrales, France; argutite et carboirite, deux nouvelles espèces minérales. Tschermaks Min Petr Mitt 31: 97-119

JuLliot J-Y, Volfinger M, RoBert J-L (1987) Experimental study of carboirite and phases in the system $\mathrm{GeO}_{2}-\mathrm{SiO}_{2}-$ $\mathrm{Al}_{2} \mathrm{O}_{3}-\mathrm{H}_{2} \mathrm{O}$ at $\mathrm{P}$ up to $2 \mathrm{kbar}$. Mineral Petrol 36: 51-69

Krivovichev SV (2012) Derivation of bond-valence parameters for some cation-oxygen pairs on the basis of empirical relationships between $r_{o}$ and $b . Z$ Kristallogr 227: 575-579

Lee CS, Weng SF (2008) A quaternary germanium (II) phosphate, $\mathrm{Na}\left[\mathrm{Ge}_{4}\left(\mathrm{PO}_{4}\right)_{3}\right]$. Acta Cryst E64: 117

Li K, XUE D (2006) Estimation of electronegativity values of elements in different valence states. J Phys Chem A 110: 11332-11337

Mandarino JA, Back ME (2004) Fleischer's Glossary of Mineral Species 2004. The Mineralogical Record Inc., Tucson, pp 1-310

Messer D (1978) Die Kristallstruktur von $\mathrm{RbGeCl}_{3}$. Z Naturforsch B 33: 366-369

Ottemann J, Nuber B (1972) Brunogeierit, ein GermaniumFerritspinell von Tsumeb. Neu Jb Mineral, Mh 263-267

Seiridonov EM, Murashro MN (2010) Genetic mineralogy of Ge, Ga, W, Mo, V, Sn in endogenic ores of the polymetallic deposit Tsumeb (Namibia). XI RMS General Meeting, pp 277-279 (in Russian). Accessed on March 4, 2013, at http://www.minsoc.ru/2010-1-101-0

Thiele G, Rotter HW, Schmidt KD (1987) Kristallstrukturen und Phasentransformationen von Caesiumtrihalogenogermanaten(II) $\mathrm{CsGeX}_{3}(\mathrm{X}=\mathrm{Cl}, \mathrm{Br}, \mathrm{I})$. Z Anorg Allg Chem 545: 148-156

Wang X, Liebau F (1996) Studies on bond and atomic valences. I. Correlation between bond valence and bond angles in $\mathrm{Sb}^{\mathrm{III}}$ in chalcogen compounds: the influence of lone-electron pairs. Acta Cryst B52: 7-15

WEAKLEY TJR (1983) The crystal structure of germanium (II,IV) phosphinate, $\mathrm{Ge}_{2}\left(\mathrm{H}_{2} \mathrm{PO}_{2}\right)_{6}$. J Chem Soc Pak 5: 279-281

Weakley TJR, Watt WWL (1979) Chloro(phosphinato) germanium(II) and Chloro(phosphinato)tin(II). Acta Cryst B35: 3023-3024

Welch MD, CoOper MA, Hawthorne FC (2001) The crystal structure of brunogeierite, $\mathrm{Fe}_{2} \mathrm{GeO}_{4}$ spinel. Mineral Mag 65: $441-444$

Williams PA, Hatert F, Pasero M, Mills SJ (2011) New minerals and nomenclature modifications approved in 2011. Mineral Mag 75: 2535-2540 